\title{
Detection of Tobacco Rattle Virus RNA in Processed Potato Chips Displaying Symptoms of Corky Ringspot Disease
}

\author{
James M. Crosslin ${ }^{1,2}$ \\ Road, Prosser, WA 99350 \\ Additional index words. potato diseases, tobraviruses
}

USDA-ARS, Vegetable and Forage Crops Research Unit, 24106 North Bunn

Abstract. In Apr. 2008, commercially purchased processed potato chips were observed with dark brown arcs and rings typical of corky ringspot disease. This disease is caused by infection with tobacco rattle virus (TRV). A portion of RNA 1 of TRV was amplified by reverse transcription polymerase chain reaction (RT-PCR) from each of eight discolored chips from three different bags purchased at three locations. Sequence analysis of the 463bp amplicons confirmed that the products were indeed TRV in origin and were $97 \%$ identical to TRV sequences of isolates originating in Washington, Florida, and Wisconsin. Extracts from the symptomatic RT-PCR-positive chips were not infectious when mechanically inoculated onto tobacco leaves. To the author's knowledge, this is the first report of the detection of plant virus RNA in a food product after high-temperature frying.

Tobacco rattle virus (TRV) is the type member of the tobravirus group. These viruses are transmitted by soil-inhabiting nematodes in the Trichodorus and Paratrichodorus genera (Harrison, 1970; Harrison and Robinson, 1986). The virus has a large host range, including numerous crop plants and weeds, and occurs in many parts of North America and Europe. Typically the virus is more common in soils with a sandy texture, which favors the nematode vector (Harrison, 1970). In the northwestern United States, the primary vector of TRV is $P$. allius (Mojtahedi et al., 2000). When the virus is transmitted to developing potato (Solanum tuberosum) tubers, internal symptoms are produced consisting of rings, arcs, and various dark blotches that may have a corky texture. Collectively, the symptoms are referred to as corky ringspot disease (CRS; Crosslin et al., 2007). If high percentages of potato tubers in a given lot show symptoms of CRS, they may be rejected by potato processors or for fresh market use, resulting in significant economic loss to the grower. Corky ringspot has been known to occur for some time in the Pacific Northwest (Mojtahedi et al., 2000), Florida, and a few other locations and was recently reported for the first time in Michigan (Kirk et al., 2008), Wisconsin, and Minnesota (Gudmestad et al., 2008).

The tobravirus genome consists of two positive sense RNA molecules. The larger RNA 1 contains four open reading frames (ORF), including those for the RNA-dependent RNA polymerase (Sudarshana and Berger, 1998). One ORF near the $3^{\prime}$ end of RNA 1 called the $16 \mathrm{kDa}$ protein ORF codes

Received for publication 22 May 2009. Accepted for publication 7 July 2009.

${ }^{1}$ Research Plant Pathologist.

${ }^{2}$ To whom reprint requests should be addressed; e-mail jim.crosslin@ars.usda.gov. for a factor reportedly involved in nematode transmissibility (Boccara et al., 1986) or possibly in virus gene regulation (Liu et al., 2002). Sequence analysis suggests that this ORF is highly conserved among American and European isolates of TRV and thus has been widely used for detection of the virus by reverse transcription polymerase chain reaction (RT-PCR) in potato foliage and tuber tissue (Crosslin and Thomas, 1995; Robinson, 1992; Weidemann, 1995). The smaller RNA 2 contains the capsid protein ORF and other nonstructural genes that may be involved in nematode transmission (MacFarlane, 1999). Tobacco rattle virus RNA 1 is infectious in the absence of RNA 2 but produces infections that lack capsid protein, because this gene is located on RNA 2 (MacFarlane, 1999).

Potato chips are processed by frying in vegetable oil at $\approx 160^{\circ} \mathrm{C}$, which would render any known plant virus inactive. Theoretically, however, the genomic RNA would be present but possibly altered by this treatment. This article reports the detection of TRV RNA in commercially purchased processed potato chips that showed symptoms typical of corky ringspot disease.

\section{Materials and Methods}

Nucleic acid extraction and reverse transcription polymerase chain reaction. In Apr. 2008, some of the potato chips in three commercially purchased bags of wavy-cut chips were observed with typical CRS symptoms of brown arcs and rings. Three of these chips are shown in Figure 1. Total nucleic acid extracts were prepared as previously described (Crosslin et al., 2006) from 300 $\mathrm{mg}$ of symptomatic tissue from three chips each of two bags and two chips from the third bag. Three symptomless regular-cut chips from another commercially purchased bag were processed as negative controls. The chip nucleic acid extracts were tested for the 16
$\mathrm{kDa}$ protein ORF of TRV by RT-PCR as previously described (Crosslin and Thomas, 1995), except that the reverse transcriptase concentration was reduced to $40 \mathrm{U}$ per reaction. Amplification products were resolved by electrophoresis through $1.5 \%$ agarose gels stained with ethidium bromide and visualized under ultraviolet light. The presence of the predicted 463-bp band (Crosslin and Thomas, 1995; Robinson, 1992) indicated the presence of viral RNA. Amplicons were purified with GeneCapsules (G-Biosciences, St. Louis, $\mathrm{MO}$ ), ligated into pCRII-Topo plasmid vectors (Invitrogen, Carlsbad, CA), and transformed into chemically competent Top 10 cells (Invitrogen). Insert size was confirmed by digestion with EcoRI and two clones were sequenced in both directions by ACGT, Inc. (Wheeling, IL) using SP6 and T7 primers.

Infectivity tests. Four hundred milligrams of tissue from each of the eight symptomatic chips tested by RT-PCR was ground with $4 \mathrm{~mL}$ of $30 \mathrm{~mm}$ potassium phosphate buffer, $\mathrm{pH} 8.0$, containing $10 \mathrm{~mm}$ sodium diethyldithiocarbamate with a mortar and pestle and separately rub-inoculated onto three Carborundum-dusted leaves of one Nicotiana tabacum 'Samsun NN'. These plants were maintained in the greenhouse and observed for development of typical TRV symptoms, including local necrotic lesions and systemic mosaic (Harrison, 1970).

\section{Results and Discussion}

Nucleic acid extracts from all eight of the CRS symptomatic chips produced a 463-bp amplicon typical of TRV when tested by RTPCR. The RT-PCR results from the three chips shown in Figure 1 are shown in Figure 2. The amplicons from the two larger chips shown in Figure 1 were excised, cloned, and sequenced as described previously. The sequences of the two amplicons were $100 \%$ identical and the sequence was entered into GenBank as accession FJ591156. Sequence analysis confirmed the amplicons were of viral origin and were $97 \%$ identical to sequences for TRV isolates reported from Washington, Florida, and Wisconsin (accessions EU315226, AF055912, and EU569291, respectively). Similarities of $95 \%$ to $96 \%$ were observed with other North American

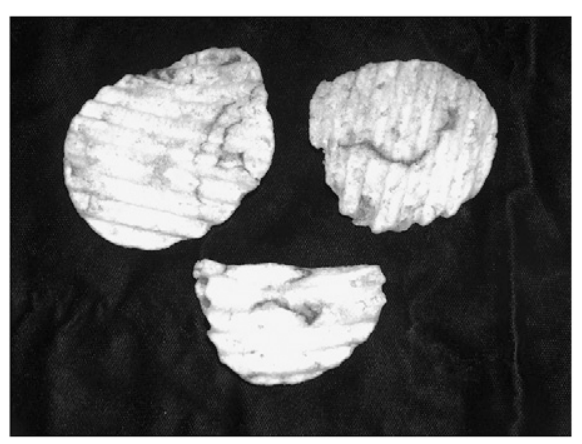

Fig. 1. Three commercially purchased potato chips showing the brown arcs and rings typical of corky ringspot disease. 


\section{12234556778 M}

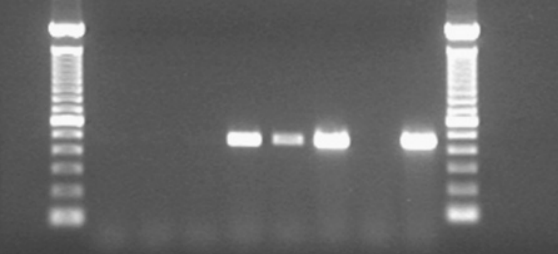

Fig. 2. Agarose gel electrophoresis of products obtained by tobacco rattle virus (TRV)-specific reverse transcription polymerase chain reaction from three symptomless chips (Lanes 1-3), the three symptomatic chips shown in Figure 1 (Lanes 4-6), healthy potato leaf tissue (Lane 7), and a TRV-infected fresh potato tuber (Lane 8). Marker lanes (M) contain a 100-bp DNA ladder. The predicted amplicon is $463 \mathrm{bp}$.

and European isolates of TRV. Extracts from three nonsymptomatic chips failed to amplify in RT-PCR (Fig. 1).

Extracts from the symptomatic chips were not infectious when inoculated onto 'Samsun NN' tobacco, as evidenced by the lack of symptom development in the inoculated plants. Isolates of TRV have been inoculated to 'Samsun NN' and maintained in this greenhouse for many years, suggesting that infectivity of the extracts would have been successfully detected. The lack of infectivity of the chip extracts is not surprising because the $160{ }^{\circ} \mathrm{C}$ temperature used for frying chips would eliminate infectivity of most, if not all, plant viruses. Also, because no plant virus is known to infect higher animals, there is no threat to human health if such chips were ingested and the economic impact consists of reduced consumer acceptability of blemished chips.

The chip manufacturer was provided with the lot number of the chips shown in Figure 1 and the cultivar and state of origin were identified. It was also learned that the grower and processor were aware that a small percentage of the potatoes showed symptoms of CRS before processing. A common industry limit for this sort of internal defect is 5\% so it is not surprising that a few chips with defects escape the quality control and sorting that takes place before product packaging and shipment.

To the author's knowledge, this is the first report of the detection of the RNA of a plant virus in a food product that has undergone high-temperature processing. These results suggest that other plant viruses may be similarly detectable in processed food products.

\section{Literature Cited}

Boccara, M., W.D.O. Hamilton, and D.C. Baulcombe. 1986. The organization and interviral homologies of genes at the $3^{\prime}$ end of tobacco rattle virus RNA-1. EMBO J. 5:223-229.

Crosslin, J.M., P.B. Hamm, K.S. Pike, T.M Mowry, P. Nolte, and H. Mojtahedi. 2007. Managing diseases caused by viruses, viroids, and phytoplasmas, p. 161-169. In: Johnson, D.A. (ed.). Potato health management 2 nd Ed. APS Press, Minneapolis, MN.

Crosslin, J.M. and P.E. Thomas. 1995. Detection of tobacco rattle virus in tubers exhibiting symptoms of corky ringspot by polymerase chain reaction. Amer. Potato J. 72:605-609.

Crosslin, J.M., G.J. Vandemark, and J.E. Munyaneza. 2006. Development of a real-time, quantitative
PCR for detection of the Columbia Basin potato purple top phytoplasma in plants and beet leafhoppers. Plant Dis. 90:663-667.

Gudmestad, N.C., I. Mallik, J.S. Pasche, and J.M. Crosslin. 2008. First report of tobacco rattle virus causing corky ringspot in potatoes in Minnesota and Wisconsin. Plant Dis. 92:1254.

Harrison, B.D. 1970. Tobacco rattle virus. Descriptions of plant viruses. No. 12. Commonwealth Mycological Institute and Association of Applied Biologists, Kew, UK.

Harrison, B.D. and D.J. Robinson. 1986. Tobraviruses, p. 339-369. In: Van Regenmortel, M.H.V. and H. Fraenkel-Conrat (eds.). The plant viruses, Vol. 2: The rod-shaped plant viruses. Plenum Press, New York, NY.

Kirk, W.W., S.L. Gieck, J.M. Crosslin, and P.B. Hamm. 2008. First report of corky ringspot caused by Tobacco rattle virus on potatoes (Solanum tuberosum) in Michigan. Plant Dis. 92:485.

Liu, H., B. Reavy, M.M. Swanson, and S.A. MacFarlane. 2002. Functional replacement of the Tobacco rattle virus cysteine-rich protein by pathogenicity proteins from unrelated plant viruses. Virology 298:232-239.

MacFarlane, S.A. 1999. Molecular biology of the tobraviruses. J. Gen. Virol. 80:2799-2807.

Mojtahedi, H., G.S. Santo, Z. Handoo, J.M. Crosslin, C.R. Brown, and P.E. Thomas. 2000. Distribution of Paratrichodorus allius and tobacco rattle virus in Pacific Northwest potato fields. J. Nematol. 32:447.

Robinson, D.J. 1992. Detection of tobacco rattle virus by reverse transcription and polymerase chain reaction. J. Virol. Methods 40:57-66.

Sudarshana, M.R. and P.H. Berger. 1998. Nucleotide sequence of both genomic RNAs of a North American tobacco rattle virus isolate. Arch. Virol. 143:1535-1544.

Weidemann, H.-L. 1995. Detection of tobacco rattle virus in potato tubers and roots by polymerase chain reaction (PCR). J. Phytopathol. $143: 455-458$ 